\author{
Wojciech Piasek \\ (Uniwersytet Mikołaja Kopernika w Toruniu) \\ https://orcid.org/0000-0002-5997-5844
}

\title{
Inne-miejsca pamięci - przypadek Urbex History
}

\author{
Non-Places of Memory - the Case of Urbex History
}

\section{STRESZCZENIE}

W artykule prezentuję wyniki badań nad zjawiskiem obecnym w kulturze współczesnej określanym jako urbex (urban exploration). Podejmuję tylko jedno z wielu zagadnień, jakie nasuwają się podczas obserwacji tego fenomenu kulturowego. Stawiam pytanie: Czym są miejsca eksplorowane w kontekście deklarowanych zainteresowań historycznych przedstawicieli urban exploration?

Przeprowadzona analiza jest studium przypadku. Badam jedną z grup zajmujących się miejską eksploracją - Urbex History. Stwierdzam, że w przeciwieństwie do miejsc pamięci Pierre'a Nory, które są „konwencjonalnie” dostępne, odwiedzane i doświadczane, miejsca eksplorowane przez członków Urbex History są heterotopiami. W kontekście pamięci historycznej są one nieoczywistymi kulturowo miejscami pamięci - tytułowymi innymi-miejscami pamięci.

Inne-miejsca pamięci i związana z nimi pamięć są wynikiem alternatywnego doświadczania przeszłości oraz innego jej praktykowania niż w przypadku miejsc pamięci. Odmienna jest także treść pamięci zogniskowana w tych miejscach. Inne-miejsca pamięci są częścią pamięci popularnej i kultury popularnej, które we współczesnej kulturze odgrywają kluczową rolę w relacji z przeszłością.

Słowa kluczowe: kultura popularna, miejsca pamięci, historiografia, pozaakademickie formy historii

W artykule zajmuję się zjawiskiem określanym w kulturze jako urbex (skrót od urban exploration) czy też infiltracja w kontekście pozaakademickich form relacji z przeszłością ${ }^{1}$. Urbex jest „odkrywaniem” niewidocznych

1 Fundamenty teoretyczne badań nad pozaakademickimi formami relacji z przeszłością przedstawiam w: W. Piasek, Etnografia myśli potocznej w dziedzinie pozaakademickich relacji z przeszłościa. Myśl potoczna jako przedmiot badań historii historiografii, „Historia@Teoria” 2017, 4, s. 53-65. 
w dosłownym znaczeniu, czy też jedynie przenośnym, miejsc opuszczonych, niedostępnych w mieście oraz poza nim. Miejsca te pozostawiane są przez ich eksploratorów w takim stanie, jak je zastali. Jedynie są fotografowane lub filmowane ${ }^{2}$. Przysłowiowy rzut oka do zasobów internetowych pozwala śmiało powiedzieć, że zjawisko to, zapoczątkowane w Europie Zachodniej pod koniec XX w., w Polsce rozwija się bardzo intensywnie. Świadczą o tym liczne blogi internetowe oraz specjalne kanały na YouTu$b^{3}$. Ma ono także swój komercyjny aspekt w postaci specjalnych programów w kanałach telewizyjnych".

W zasadzie wszystkie grupy urbex jednoznacznie deklaruja, że to, co robia, związane jest z odkrywaniem przeszłości i ocaleniem od zapomnienia. Poza tym aspektem, który określam jako pamięciowy, wyraźnie rysuje się także aspekty estetyczny i historiozoficzny. Specyfika miejsc opuszczonych, znajdujących się w stanie rozkładu, ruiny, które często „opanowane" są przez przyrodę, skłania do ich odbioru w kategoriach estetycznych, takich jak: malowniczość, groza, tajemniczość czy też historiozoficznych: przemijania, śmierci, zaniku, destrukcji, ale i trwałości. Urbex interesuje mnie przede wszystkim w jego aspekcie pamięciowym, w kontekście pozaakademickich form relacji z przeszłością ${ }^{5}$. Ponadto $\mathrm{w}$ artykule poruszam tylko jedno z wielu zagadnień, jakie nasuwają się podczas obserwacji tego fenomenu kulturowego w kontekście pozaakademickich form relacji z przeszłością. Interesuje mnie specyfika miejsc, które są eksplorowane i czym one są w kontekście deklarowanych zainteresowań historycznych przedstawicieli ruchu urban exploration.

2 Zob. „definicję" urbex Jeffa Chapmana uznawanego za „założyciela” urbex, http:// www.infiltration.org/ethics-nodisclaimer.html [dostęp: 27 XII 2017].

3 Zob. np.: Kierunek Urbex, https://www.youtube.com/channel/UCqraNkpnVQiLDTow1LZuxyw [dostęp: 27 XII 2017]; Urbex Polska, https://www.youtube.com/user/NaszaRzeczywistosc/featured [dostęp: 27 XII 2017]; sietra, https://www.youtube.com/user/sietra, [dostęp: 27 XII 2017]; Urban Squad, https://www.youtube.com/channel/UCuOdHq5tfz1jTO3Y2p7vk1A [dostęp: 27 XII 2017]; Urbex BC, https://www.youtube.com/user/paciej123/ featured [dostęp: 27 XII 2017].

4 Programy: „Wstęp wzbroniony” w TVN Turbo, „Urbex” w Red Bull TV.

5 Dotychczas ruchem tym zajmowano się przede wszystkim w kontekście uprawiania w Polsce turystyki i zapomnianego dziedzictwa oraz tendencji współczesnej kultury do fascynacji ruinami. M. Nieszczerzewska, Turystyczna eksploracja alternatywnego dziedzictwa, „Turystyka Kulturowa” 2016, 3, s. 42-55; eadem, Vanitas. Ruina jako przestrzeń (bez) graniczna, "Annales Universitatis Paedagogicae Cracoviensis. Studia Poetica III" 2015, s. 68-79; eadem, Miejska eksploracja. Aktywacja bez interwencji? , „Kultura i Historia” 2016, 30; W. Pokojska, Zapomniane dziedzictwo, urban exploring, "Zarządzanie w Kulturze" 2015, 16, s. 151-163; eadem, Turystyka miejsc niechcianych - poradzieckie garnizony w Polsce Zachodniej, „Turystyka Kulturowa” 2016, 2, s. 101-105; A. Stronciwilk, Ruiny. Groza i fascynacja, „Art Papier" 2012, 204, s. 1-4. Zob. także „Widok. Teorie i Praktyki Kultury Wizualnej” 2013, 4. Numer ten poświęcony jest w całości miejscu ruin we współczesnej kulturze. 
Chcąc poruszać się po „szorstkim gruncie”, swoją analizę przeprowadzam na przykładzie jednej z grup zajmujących się miejską eksploracją. Grupa Urbex History jest jedyną z polskich grup, która aspekt pamięciowy uznaje za konstytutywny dla siebie. Tworzy ją trzech młodych mężczyzn. Sami o sobie i o tym, co robia, piszą:

Siema! Jesteśmy trójką przyjaciół wchodzących tam, gdzie nie wolno (:) i razem tworzymy ekipę Urbex History! Odwiedzamy zapomniane i opuszczone miejsca, które często nie są dostępne dla przeciętnego śmiertelnika, aby następnie nagrać o nich film ubarwiony w historyczny komentarz. [...] Bardzo często podróżujemy po Polsce, aby przybliżyć Wam historię tego pięknego kraju, oczywiście w naszym stylu'

Na swoim kanale YouTube, gdzie publikują filmy z wypraw, przedstawiają się jako „grupa eksploratorów z pasją do historii. Zwiedzamy i filmujemy opuszczone miejsca, często tajne lub niedostępne dla wszystkich. W każdym z naszych materiałów o Urbex jest motyw historyczny, co nas wyróżnia na tle innych ekip"7.

Kanał YouTube grupy Urbex History subskrybuje ponad 214 tys. osób. Poszczególne filmy mają od 30 tys. do ponad 200 tys. wyświetleń ${ }^{\text {. A profil }}$ na portalu społecznościowym Facebook obserwuje ponad 16 tys. osób9 Na kanale opublikowano m.in. filmy: Opuszczony Browar Mycielskich, Tajna Hitlerowska Torpedownia na Bałtyku, Betonowe kolosy zakłady zbożowe PZZ Kozłów, Podwodne tajemnice fortu Zbarż, Podziemia Fortu Winiary - Poznań, Wieżowiec Prudential - najwyższy powstaniec 1944 r., Cmentarzysko pociagów PKP Płaszów, Urbex Live Kwatera Atomowa, Tajne radzieckie miasto w Polsce - Pstraże, Opuszczona ambasada rosyjska w Warszawie, Opuszczona gazownia, Opuszczone przedszkole nr 187, Opuszczona szkoła petna wyposażenia, Opuszczona odnowa biologiczna i hotel, Opuszczony burdel i willa, Opuszczony radiowy ośrodek badawczy, Pamiętniki z kolonii: opuszczone letnisko z PRL $L^{10}$.

Nie jest zaskoczeniem, że pierwsze kroki w próbach określenia eksplorowanych przez Urbex History miejsc kieruję do kategorii miejsc pamięci wprowadzonej do dyskursu naukowego przez Pierre'a Norę. Kategoria miejsca, już nie w kontekście pamięci, jest jeszcze obecna we francuskiej refleksji u co najmniej dwóch jej przedstawicieli. Marc Augé, antropolog społeczno-kulturowy, pisze o nie-miejscach, Michel Foucault o heterotopiach. Bliższe przyjrzenie się im i skonfrontowanie z miejscami pamięci

6 https://patronite.pl/urbexhistory [dostęp: 27 XII 2017].

7 https://www.youtube.com/user/urbexhistory/about [dostęp: 27 XII 2017].

8 Zob. https://www.youtube.com/user/urbexhistory [dostęp: 27 XII 2017].

9 Zob. https://www.facebook.com/pg/historiazapomnianych/about/?ref=page_internal [dostęp: 27 XII 2017].

10 Zob. https://www.youtube.com/user/urbexhistory [dostęp: 27 XII 2017]. 
Nory pozwoli określić specyfikę miejsc odwiedzanych przez Urbex History.

Pojęcie miejsc pamięci ulegało ewolucji w trakcie realizowania zamierzonego przez Norę projektu inwentaryzacji pamięci narodowej Francuzów. Było to niewątpliwie związane z krytyką jego koncepcji. Nie ma potrzeby referować tej krytyki. Chciałbym jedynie zwrócić uwagę na jeden z wątków, który w tej krytyce występuje i jest ważny dla podjętego przeze mnie zagadnienia. Przyjmuje on różne formy. Hue-Tam Ho Tai zwraca uwagę na nieuwzględnienie przez Norę pamięci regionalnej, świata imigrantów oraz specyficznych rodzajów pamięci społecznej rozumianej klasycznie, np. chłopów, robotników, jak i nieklasycznie, kobiet ${ }^{11}$. Komentujący zarzuty wobec Pierre'a Nory Georg Kreis trafnie podsumowuje, iż w projekcie badacza nie zostali uwzględnieni ci, którzy byli nosicielami counter-memory ('przeciw pamięci') ${ }^{12}$. Zwraca również uwagę, iż wybór haseł przynajmniej do dwóch tomów Le lieux de mémoire to wybór „oczywistych i nader oczywistych oczywistości”. Pierre Nora koncentruje się na miejscach należących, według niego, do większości ${ }^{13}$. Poza tym są to w zasadzie tylko „znaczące” miejsca ${ }^{14}$. Reasumując te uwagi, należy zauważyć, że ich cechą wspólną jest przekonanie o włączeniu do miejsc pamięci - nie tylko z punktu widzenia badacza, ale przede wszystkim badanych, kulturowych „oczywistych oczywistości” związanych z narodową tożsamością Francuzów.

Warto jeszcze zwrócić uwagę na fundament projektu Nory, którym jest inwentaryzacja narodowej tradycji. Zastanawiając się nad współczesnymi zmianami, badacz podkreśla, iż pamięć i miejsca pamięci stanowią ostoję francuskiej tożsamości. Nie ma już żywej pamięci, ilustrowanej „przez społeczeństwa prymitywne lub archaiczne, których ma być jednocześnie sekretem", zanikła ona wraz z kulturą wiejską. W miejsce kultury wiejskiej, tej kluczowej przechowalni pamięci i tożsamości, weszła pamięć uhistoryczniona ze swoimi miejscami pamięci ${ }^{15}$.

Marc Augé nie-miejsca przeciwstawia miejscom antropologicznym. Charakterystyczne dla dzisiejszej hipernowoczesności nie-miejsca są według niego miejscami przechodnimi i światami bez pamięci i historii. Stanowią one ziemię niczyja, punkty tranzytowe związane $\mathrm{z}$ chwilą i zmien-

11 G. Kreis, Pierre Nora - lepsze rozumienie i krytyka, w: Konteksty pamięci. Antologia, red.

K. Kończal, Warszawa 2014, s. 376.

12 Ibidem.

13 Ibidem, s. 377.

14 Ibidem, s. 380.

15 P. Nora, Między pamięcia a historią. Les lieux de mémoire, „Tytuł Roboczy. Archiwum” 2009, 2, s. 4. 
nością. Miejsca antropologiczne nie zniknęły, czego dowodem są dla Augé choćby „miejsca pamięci”. Jego zdaniem to jednak nie one są emblematem naszej epoki. Teraźniejszość hipernowoczesności wyznaczają „niemiejsca"16. Dariusz Czaja, antropolog kultury, przyglądając się koncepcji Marca Augé, słusznie zwraca uwagę, iż jego kategoria jest wartościująca. Koncepcja nie-miejsca, pisze on:

[...] okazuje się nie tylko opisem wielce prozaicznych - wspartych na tymczasowości i efemeryczności - form dzisiejszego zamieszkania, ale również słabo maskowaną krytyką logiki świata późnego kapitalizmu, o ile nie łzawym lamentem nad współczesnym procesem alienacji i dehumanizacji. I w tym jego widoczna słabośćc ${ }^{17}$.

Charakter nie-miejsc Augé zbudowany jest na wartościujących przeciwieństwach, takich jak swojskie - obce, statyczne - dynamiczne, trwałe - efemeryczne, konkretne - ogólne, imienne - anonimowe, porządkujące - anarchiczne ${ }^{18}$. Jak widać "nie-miejsce” jest terminem wyraźnie negatywnym. Pełni funkcję opisowa, ale jednocześnie stygmatyzuje. Dariusz Czaja słusznie dopatruje się tu niewypowiedzianego wprost pragnienia rewitalizacji nie-miejsc - ukrytego dydaktyzmu. Marc Augé chciałby ich włączenia na powrót do sieci miejsc prawdziwych. Jak zauważa Czaja, dla Augé „w nie-miejscach nie mieszkamy [...] naprawdę, zaledwie w nich przebywamy, nie ma więc powodów, by konserwować ich istnienie"19.

Idźmy dalej za Czają i jego refleksją nad nie-miejscami, koncentrując się na tych uwagach badacza, które są przydatne do określenia specyfiki miejsc eksplorowanych przez członków Urbex History. Konfrontuje on nie-miejsca Augé z heterotopiami Foucaulta ${ }^{20}$. Zwraca uwagę, że kategoria heterotopii pozbawiona jest obecnego u Augé elementu wartościującego. Pozwala to na zdystansowanie się od jego moralizatorstwa ${ }^{21}$. Michel Foucault wskazuje na istnienie i funkcjonowanie w kulturze miejsc szczególnych, wyjątkowych, osobliwych, „innych”, do których według Czai przynależą także nie-miejsca Augé.

Według Foucaulta obok aspektu wewnętrznego przestrzeni kultury istnieje jej aspekt zewnętrzny. Tego ostatniego dotyczy pojęcie heterotopii. W każdej kulturze istnieją miejsca, które są: 2010.

16 M. Augé, Nie-miejsca. Wprowadzenie do antropologii hipernowoczesności, Warszawa

17 D. Czaja, Nie-miejsca. Przybliżenia, rewizje, w: Inne przestrzenie, inne miejsca. Mapy i terytoria, red. idem, Wołowiec 2013, s. 12.

18 Ibidem.

19 Ibidem.

20 M. Foucault, Inne przestrzenie, „Teksty Drugie” 2005, 6, s. 117-125.

21 D. Czaja, op. cit., s. 13. 
[...] w pewien sposób poza wszystkimi miejscami, choć można wskazać ich lokalizacje. Są od nich w istotnym znaczeniu odmienne (hetereos), inne, osobliwe [podkr. W.P.] [...] Heterotopie znajdują się $\mathrm{w}$ pół drogi między oswojonym i znanym miejscami rzeczywistym (topos) a miejscem pozbawionym realnej przestrzeni, istniejącym jako byt wyobrażony, pomyślany (ou-topos). Heterotopia jest, ale istnieje inaczej niż miejsca rutynowo dostępne, odwiedzane i doświadczane. Pozostaje w relacji niewspółmierności z resztą otaczającej ją przestrzeni. Funkcjonuje w niej jako byt inny, osobny, wyróżniony. Jest wyrwą w uporządkowanej strukturze przestrzennej ${ }^{22}$.

Nie-miejsca Augé nie są kategorią tożsamą z heterotopiami Foucaulta. Nie-miejsca dotyczą świata późnego kapitalizmu w wersji zachodniej, heterotopie zaś odnoszą się do kultury w ogóle. Istotniejszą różnicą jest jednak to, że te pierwsze mają być według Augé miejscami pozbawionymi znaczeń. Jako obszary tranzytowe są jakoby pozbawione jakiegokolwiek sensu. Należy się zgodzić z Czają, iż jest to duże uproszczenie i nie ma czegoś takiego jak nie-miejsca pozbawione znaczeń. Przyglądając się kilku uznanym za modelowe przykłady nie-miejsc: autostradom, terminalom lotniczym, halom dworcowym, Czaja przekonująco argumentuje, że jest przeciwnie:

Możliwe - pisze - że cała ta semantyczna podszewka nie jest dostrzegalna na pierwszy rzut oka [...], ale ona jest, istnieje. Może więc zadeklarowana przez badacza pusta semioza nie-miejsc jest tylko iluzją poznającego rozumu, efektem skrzywienia perspektywicznego, a może metodologicznych (ideologicznych) przesądzeń i wmówień23

Po usunięciu tej, jak się wydaje kluczowej różnicy, należy uznać, iż nie-miejsca, tak jak i heterotopie, dotyczą miejsc w kulturze, które są inne, obce w stosunku do jej oswojonych obszarów, które na różne sposoby sprzeciwiają się przestrzeniom wokół nich² ${ }^{24}$ Miejsc, które są przeciwmiejscami w znaczeniu inności wobec otoczenia. Co ważne, inność tych miejsc nie jest jednoznacznie określona. Jest ona konkretyzowana w ramach określonych kultur i na wiele sposobów.

Wróćmy teraz do miejsc pamięci Nory. Tu również, jak u Augé, charakter miejsc pamięci zbudowany jest w wyniku dokonanego wartościowania i pewnego dydaktyzmu. Różnica polega na tym, że wartościowanie nie jest budowane na explicite wyrażonym przeciwstawieniu i jest odwrócone w ocenie w stosunku do tego, jak występuje to u Augé. U Nory zamiast stygmatyzacji mamy do czynienia z afirmacją wyróżnionych przez niego miejsc. Jest to jednak sprawa drugorzędna. Zauważmy, że nie-miejsca Augé i miejsca pamięci Nory znajdują się na przeciwległych biegunach

\footnotetext{
${ }^{22}$ Ibidem, s. 14.

23 Ibidem, s. 18.

24 Ibidem, s. 15.
} 
kulturowej rzeczywistości. Z jednej strony mamy kulturowe osobliwości, odmienności, nie-miejsca, z drugiej - „oczywiste oczywistości”, miejsca pamięci. W swojej narodowej optyce i tęsknocie za jednością miejsca pamięci są wspominanymi już „oczywistymi oczywistościami”.

Czym są zatem miejsca odwiedzane przez członków Urbex History? W przeciwieństwie do miejsc Nory, które są „konwencjonalnie” dostępne, odwiedzane i doświadczane, są one, podobnie jak nie-miejsca, które w kulturze współczesnej zidentyfikował Augé, heterotopiami. W kontekście pamięciowym są one nieoczywistymi kulturowo miejscami pamięci - tytułowymi innymi-miejscami pamięci. Zwróćmy uwagę, że będąc innymi-miejscami pamięci, nie mieszczą się w znanej dychotomii zaproponowanej przez Aleidę Assmann. Rozważając kwestie dynamiki pamięci kulturowej, wyróżnia ona pamiętanie aktywne i bierne. Aktywna pamięć funkcjonalna zachowuje przeszłość w postaci kanonu. Bierna pamięć magazynująca - w formie archiwum. Badaczka zwraca przy tym uwagę na kwestię zapominania, wynikającą z czynników nie tylko biologicznych, ale i kulturowych: uprzedzenia, zainteresowania. Tu również wyróżnia dwie formy: zapominanie aktywne i bierne. Pierwsza to wynik zamierzonych czynności, takich jak wyrzucanie i niszczenie. Druga dotyczy niezamierzonych czynności, takich jak: „utrata, ukrycie, rozproszenie, zaniedbanie, porzucenie $[. .$.$] pozostawienie" { }^{\prime 25}$. Ślady przeszłości wypadają tu poza obręb uwagi, czci lub użytku. Mogą one na nowo wejść do pamiętania. Inne-miejsca pamięci związane są niewątpliwie ze śladami przeszłości, które zostały biernie zapomniane. Nie ujawniają one jednak jedynie aktualnego stanu niepamiętania. $W$ ten sposób byłyby rewersem zinstytucjonalizowanej pamięci kulturowej. Inne-miejsca pamięci i związana z nimi pamięć są raczej wynikiem alternatywnego doświadczania przeszłości oraz innego jej praktykowania niż w przypadku miejsc pamięci i związanej z nimi pamięci. Odmienna jest także treść pamięci zogniskowana $w$ tych miejscach. Inne-miejsca pamięci są częścią pamięci popularnej i kultury popularnej, które we współczesnej kulturze odgrywają kluczową rolę w naszej relacji z przeszłością ${ }^{26}$. Kultura popularna stanowi kontekst teoretyczny dla szczegółowej charakterystyki innych-miejsc pamięci oraz podejmowanych działań przez członków Urbex History.

25 A. Assmann, Między historia a pamięcia. Antologia, Warszawa 2013, s. 75.

26 Por. M. Krajewski, Kultury kultury popularnej, Poznań 2003. 


\section{BIBLIOGRAFIA (REFERENCES)}

\section{Opracowania}

Assmann A., Między historia a pamięcią. Antologia, Warszawa 2013.

Augé M., Nie-miejsca. Wprowadzenie do antropologii hipernowoczesności, Warszawa 2010.

Czaja D., Nie-miejsca. Przybliżenia, rewizje, w: Inne przestrzenie, inne miejsca. Mapy i terytoria, red. D. Czaja, Wołowiec 2013.

Foucault M., Inne przestrzenie, „Teksty Drugie” 2005, 6.

Krajewski M., Kultury kultury popularnej, Poznań 2003.

Kreis G., Pierre Nora - lepsze rozumienie i krytyka, w: Konteksty pamięci. Antologia, red. K. Kończal, Warszaw 2014.

Nieszczerzewska M., Miejska eksploracja. Aktywacja bez interwencji?, „Kultura i Historia” 2016, 30, http://www.kulturaihistoria.umcs.lublin.pl/archives/5980 [dostęp: 27 XII 2017].

Nieszczerzewska M., Turystyczna eksploracja alternatywnego dziedzictwa, „Turystyka Kulturowa" 2016, 3.

Nieszczerzewska M., Vanitas. Ruina jako przestrzeń (bez)graniczna, "Annales Universitatis Paedagogicae Cracoviensis. Studia Poetica III" 2015.

Nora P., Między pamięcia a historia. Les lieux de mémoire, „Tytuł Roboczy. Archiwum” 2009, 2.

Piasek W., Etnografia myśli potocznej w dziedzinie pozaakademickich relacji z przeszłościa. Myśl potoczna jako przedmiot badań historii historiografii, „Historia@Teoria” 2017, 4.

Pokojska W., Turystyka miejsc niechcianych - poradzieckie garnizony w Polsce Zachodniej, „Turystyka Kulturowa" 2016, 2.

Pokojska W., Zapomniane dziedzictwo, urban exploring, "Zarządzanie w Kulturze” 2015, 16.

Stronciwilk A., Ruiny. Groza i fascynacja, „Art Papier” 2012, 204.

„Widok. Teorie i Praktyki Kultury Wizualnej” 2013, 4.

\section{Źródła internetowe}

https://www.facebook.com/pg/historiazapomnianych/about/?ref=page_internal [dostęp: 27 XII 2017].

https://patronite.pl/urbexhistory: dostęp 27.12.2017 [dostęp: 27 XII 2017].

http://www.infiltration.org/ethics-nodisclaimer.html [dostęp: 27 XII 2017].

https://www.youtube.com/user/urbexhistory/about [dostęp: 27 XII 2017].

https://www.youtube.com/user/urbexhistory [dostęp: 27 XII 2017].

https://www.youtube.com/user/urbexhistory [dostęp: 27 XII 2017].

https://www.youtube.com/channel/UCqraNkpnVQiLDTow1LZuxyw [dostęp: 27 XII 2017].

https://www.youtube.com/user/NaszaRzeczywistosc/featured [dostęp: 27 XII 2017].

https://www.youtube.com/user/sietra [dostęp: 27 XII 2017].

https://www.youtube.com/channel/UCuOdHq5tfz1jTO3Y2p7vk1A [dostęp: 27 XII 2017].

https://www.youtube.com/user/paciej123/featured [dostęp: 27 XII 2017].

\section{ABSTRACT}

The article presents the results of research on the phenomenon known in contemporary culture as urbex (urban exploration). I focus on just one of many issues relevant to this cultural phenomenon. I pose the question: In the context of the declared historical interests of those who engage in urban exploration, what are the explored places?

The analysis is a case study of Urbex History, a group involved in urban exploration. I find that, contrary to Pierre Nora's concept of the sites of memory, which are accessible, visited and experienced, the places explored by the members of Urbex History are hete- 
rotopias. As they are connected with historical memory, they are culturally non-apparent sites of memory - the titular non-places of memory.

Such (non-)sites of memory and the memory associated with them are the result of an alternative experience of the past and practices of the past different than in the case of regular sites of memory. The contents of memory focused in these places is also different. They are a part of popular memory and popular culture, which play a key role in the relation with the past in contemporary culture.

Key words: popular culture, places of memory, historiography, non-academic forms of history

\section{NOTA O AUTORZE}

Wojciech Piasek - adiunkt w Instytucie Historii i Archiwistyki Uniwersytetu Mikołaja Kopernika, metodolog historii, historyk historiografii. W latach 1990-1995 studiował w Instytucie Archeologii i Etnologii UMK (indywidualny program studiów w zakresie etnoarcheologii), w latach 1992-1996 - w Instytucie Historii i Archiwistyki UMK. W okresie 2011-2016 pełnił funkcję redaktora naczelnego "Rocznika Antropologii Historii”. Przewodniczący Rady Naukowej serii „Chronos/Anthropos. Biblioteka Centrum Badań Antropologii Historii". Jego zainteresowania badawcze to: etnografia myśli współczesnej w dziedzinie historii i pozaakademickich form historii. Autor książek: Antropologizowanie historii. Studium metodologiczne twórczości Witolda Kuli (Poznań 2004); Historia jako wiedza lokalna. Antropologiczne przesunięcie w badaniach nad historiografią PRL (Toruń 2011); redaktor i współredaktor m.in.: K. Górski, Społeczne podstawy kultury. Zbiór prac (Toruń 2006); Rzeczy i ludzie. Humanistyka wobec materialności (Olsztyn 2008); Antropologizowanie humanistyki. Zjawisko - proces - perspektywy (Olsztyn 2009); Nowa archiwistyka - archiwa i archiwistyka w ponowoczesnym kontekście kulturowym (Torun 2014); Ludwik Kolankowski. Dzieło i życie indywidualny przypadek historiograficzny (Torun 2017). E-mail: piasek@umk.pl 